\title{
Аналіз ефективності тепличного ґрунтового регенератора гранульованою насадкою
}

\author{
І. Л. Бошкова ${ }^{1 凶}$ Н. В. Волгушева ${ }^{2}$, Е. І. Альтман ${ }^{3}$,. І. Мукмінов ${ }^{4}$, А. П. Гречановський \\ ${ }^{1-4}$ Одеська національна академія харчових технологій, вул. Канатна, 112, Одеса, 65039, Україна; \\ ${ }^{5}$ Одеський національний політехнічний університет, просп. Шевченка, 1, Одеса, 65044, Україна \\ $\triangle$ e-mail: ${ }^{1}$ boshkova.irina@gmail.com; ${ }^{2}$ natvolgusheva@gmail.com; ${ }^{3}$ ellaa@ukr.net; ${ }^{4}$ fatalrew@gmail.com \\ ORCID: ${ }^{1}$ http://orcid.org/0000-0001-5989-9223; ${ }^{2}$ http://orcid.org/0000-0002-9984-6502; \\ ${ }^{3}$ http://orcid.org/0000-0001-6454-2819; ${ }^{4}$ https://orcid.org/0000-0002-3674-9289
}

\begin{abstract}
Акутальним в наш час є пошук ефективних акумуляторів сонячної енергії для обігріву приміщень в умовах значного добового перепаду температур. В якості акумулюючого тіла доиільно застосовувати щільний шар гранульованих матеріалів. Вивчено можливість застосування теплообмінного апарату регенеративного типу з гранульованою насадкою у вигляді щільного шару. Нагрівання гранульованої насадки здійснюється потоком повітря з внутрішнього простору. Проектований регенератор призначений для підтримки необхідного температурного рівня. Ідея створення трунтового регенератора трунтується на відомостях про інтенсивність нагріву повітря в теплиці від сонячного випромінювання в денний час і ефективності контактного теплообміну між повітрям $i$ шаром частинок. Пропоноване схемне рішення передбачає забір повітря з верхньої частини теплииі, щз забезпечує подачу потоку повітря в канал при максимальній температурі. Розглядається застосування щзільного шару щебню в якості теплообмінної насадки. Представлені ре-

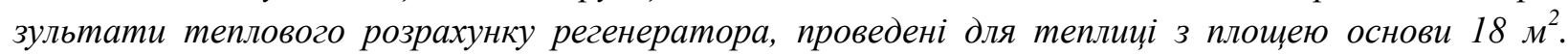
Кліматичні умови відповідають регіонам з помірним кліматом, наприклад, Одеській області. Для середнього рівня інсолячії, характерного для квітня, $i$ заданої тривалості нагріву шару, визначені основні геометричні характеристики теплообмінних каналів. Наведено результати попереднього розрахунку теплових втрат від теплиці в нічний час і час, протягом якого теплота, акумульована регенератором, буде йти на обігрів внутрімнього обсягу теплиці. Отримано, щзо акумульована теплота дозволяє підтримувати допустиму температуру в теплиці протягом 2,5 години без застосування інших засобів обігріву. При підвищенні температури навколишнього середовища час роботи регенератора буде збільшуватися, що сприяє більшому зниженню енергетичних витрат на підтримку клімату в теплиці.
\end{abstract}

Ключові слова: Теплиия; Сонячне випромінювання; Акумуляиія теплоти; Регенератор; Теплообмінний канал; Щільний шар

\section{doi: https://doi.org/10.15673/ret.v56i3-4.1946}

(C) The Author(s) 2020. This article is an open access publication

This work is licensed under the Creative Commons Attribution 4.0 International License (CC BY) http://creativecommons.org/licenses/by/4.0/

\section{1. Вступ}

Зусилля багатьох дослідників спрямовані на пошук ефективних акумуляторів сонячної енергії для обігріву приміщень в умовах значного добово- го перепаду температур [1-5]. Дослідження показують, що в якості акумулюючого тіла доцільно застосовувати щільний шар гранульованих матеріалів [6]. Одним з додатків застосування теплообмінного апарату з гранульованою насадкою у ви- 
гляді щільного шару, для якого джерелом теплоти $\epsilon$ сонячне випромінювання, $є$ регенератор для підтримання необхідного температурного рівня в теплицях. Температура в теплиці в середньому повинна складати від +16 до $+25^{\circ} \mathrm{C}$, а вночі спадати не більше, ніж на 5-8 ${ }^{\circ} \mathrm{C}$. Температура нижче і вище норми для рослин небажана. Відомо, що повітря в теплицях в весняний період в регіонах з помірним кліматом в денний час інтенсивно нагрівається від сонячного випромінювання, а в нічний через перепад температур істотно охолоджується. Це визначає раціональність розробки регенератора, здатного акумулювати теплоту днем і використовувати іiі для обігріву внутрішнього обсягу теплиці вночі. Актуальність роботи визначається необхідністю економії енергетичних ресурсів на обігрів приміщень, зокрема, теплиць.

\section{2. Аналіз літературних джерел}

В роботі [7] представлені результати експериментального дослідження енергетичного балансу теплиці без підігріву в умовах жаркого і посушливого клімату. Показано, що тепличний грунт $\epsilon$ важливим джерелом тепла в нічний час і може забезпечити приблизно до 44,03 Вт/м² при значній добовій інсоляції. У порівнянні з системою штучного опалення, яка вимагає приблизно $78 \mathrm{BT} / \mathrm{m}^{2}$, таке джерело тепла буде достатнім для підтримки температури повітря в теплиці між 15 i $18{ }^{\circ} \mathrm{C}$. Однак наведені результати розрахунків застосовні для умов проведення експериментів, тобто в регіоні Середземноморського басейну. У той же час результати свідчать, що акумуляція теплоти грунтом теплиці здатна істотно знизити енергетичні витрати. В роботі [8] відзначається основна проблема, що гальмує використання всього потенціалу природних і відновлювальних джерел енергії. Застосування сонячної енергії в системах обігріву і охолодження приміщень неможливо без розробки економічно конкурентоспроможних і надійних засобів для акумулювання теплоти. В [9] досліджуються різні методи акумулювання сонячної теплової енергії, при цьому основна увага приділяється насипному і киплячого шару. Встановлено, що щільні шари мають основну перевагу в низькотемпературних системах накопичення енергії. Внаслідок доцільності застосування щільних шарів як теплових акумуляторів проводяться дослідження ефективності їх застосування в різних умовах. На основі тривимірного аналізу потоків газу в шарі алюмінієвих куль встановлено [10], що зменшення діаметра кульок значно збільшує градієнт тиску, швидкість потоку знижується. Отримані дані дозволяють оптимізувати розміри регенератора 3 щільним шаром частинок. Дослідження теплопереносу в щільних шарах [11] дозволили зробити висновок, що при проектуванні шару для накопичення теплової енергії число Біо має бути якомога нижче. В цьому випадку тепловий опір всередині твердого тіла не $\epsilon$ визначальним. При виборі матеріалу для насадки доцільно враховувати цю умову. Важливо також створення умов для інтенсифікації теплообміну. Виявлено[12], що вплив форми контакту на перепади тиску $є$ значним, а на числа Нуссельта вплив відносно невеликий. Однак дані відносяться до шару сферичних частинок, що не дозволяє їх поширити на шар частинок 3 довільною формою поверхні.

Процес нагріву і охолодження теплиці $\epsilon$ нестаціонарним, що істотно ускладнює математичне моделювання та отримання залежностей для розрахунку температур і теплових потоків. Ця проблема може бути усунена при використанні наближення, що застосовується авторами [13]. Як показано в роботі, для проведення оціночних розрахунків раціонально використовувати наближення до стаціонарних умов при заданих середніх значеннях температур і теплових потоків. Ще однією проблемою є невизначеність коефіцієнта тепловіддачі від поверхні частинок до газового потоку. В роботі [14] представлена залежність для визначення коефіцієнта тепловіддачі, або коефіцієнта міжкомпонентного теплообміну, від щільного шару часток сферичної форми до потоку газу. Однак пропонована залежність може бути застосована для стаціонарного режиму теплообміну між рухомим шаром частинок і потоком газу. Автори роботи [15] представили результати експериментального дослідження тепловіддачі в циліндричному насадочному шарі сферичних пористих частинок оксиду алюмінію. Запропоновано методику обробки експериментальних даних і напівемпіричну модель, пропоновану для прогнозування коефіцієнта тепловіддачі від газу до частинкам при моделюванні процесів сушіння і спалювання. Автори наводять результати зіставлення різних кореляцій для коефіцієнтів тепловіддачі. Як висновок - загальна залежність для розрахунку коефіцієнта тепловіддачі між шаром частинок і газовим потоком не існує. Кожен окремий випадок теплообміну потребує відповідної кореляційної залежності. Слід 
зазначити, що в літературі використовується два терміни: коефіцієнт тепловіддачі або коефіцієнт міжкомпонентного теплообміну. Останній видається кращим, оскільки конкретизує специфіку процесу теплообміну, при якому твердий і газовий теплоносії безпосередньо контактують між собою. Як наголошується в [6], при теплообміні з нерухомим гранульованим шаром коефіцієнт міжкомпонентного теплообміну істотно залежить від часу, i ця залежність має форму сигмоїди. Для отримання розрахункової формули необхідно проведення додаткових досліджень. Аналіз літературних даних [9-12] свідчить, що розробка регенераторів з щільними шарами гранульованих матеріалів є перспективною щодо розвитку енергозберігаючих систем нагрівання та охолодження.

Метою роботи є оцінка ефективності грунтового регенератора 3 гранульованою насадкою у вигляді щільного шару матеріалу для підтримки необхідного температурного рівня в теплицях в денний і нічний час.

\section{3. Аналітичне дослідження роботи ґрунто- вого регенератора 3 нерухомим щільним шаром гранульованого матеріалу}

Ідея створення грунтового регенератора грунтується на відомостях про інтенсивність нагріву повітря в теплиці від сонячного випромінювання в денний час і ефективності контактного так теплообміну між повітрям і шаром частинок. Схемне рішення передбачає забір повітря з верхньої частини теплиці, що забезпечує подачу потоку повітря в канал при максимальній температурі. Таким чином, здійснюється як нагрів щебню в каналі, так i зниження температури повітря в теплиці, що захищає рослини від перегріву. Схема розташування грунтового регенератора в теплиці представлена на рис. 1. У запропонованій схемі здійснюється безпосередній контакт повітря і матеріалу, який акумулює теплоту. У цьому випадку немає необхідності в проміжному теплоносії і відсутні додаткові термічні опори. Крім того, застосування гранульованого матеріалу забезпечує розвинену теплообмінну поверхню. Все це сприяє ефективному протіканню теплообмінних процесів. При розробці схемного рішення регенератора враховувалося, що найбільша температура повітря в теплиці - вгорі. Тому забір повітря повинен здійснюватися під дахом теплиці. У періоді нагріву повітря по повітропроводу 3 нагнітається вентилятором 4 в тепло- обмінний канал 23 гранульованим матеріалом 1, нагріваючи його. Для зниження теплових втрат теплообмінний канал покривається ізоляцією 5. Теплообмінний канал розташовується під грунтом теплиці 6. В періоді охолодження теплота від нагрітого гранульованого матеріалу передається повітрю, що проходить по каналу. Нагріте повітря надходить у внутрішній обсяг теплиці, нагріваючи його.

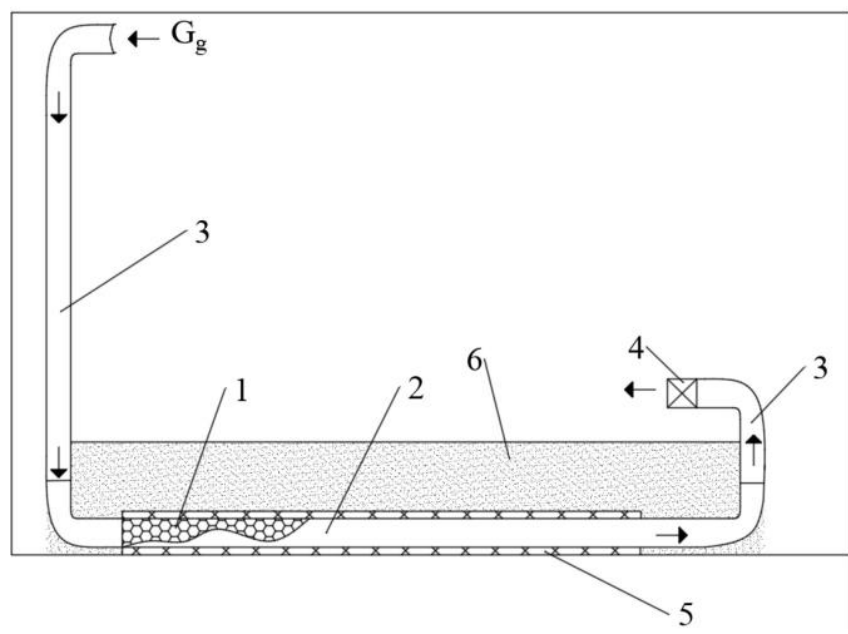

Рисунок 1 - Схема розташування трунтового регенератора в теплиці: 1 - гранульований матеріал, 2 - теплообмінний канал,

3 - повітропровід, 4-витяжний вентилятор, 5 - ізоляція, 6- трунт в теплицуі

Методика розрахунку, розроблена авторами роботи, наведена в [6]. Для проведення розрахунку необхідно вибрати гранульований матеріал 3 еквівалентним діаметром частинок $d_{\mathrm{e}}$. Слід поставити такі величини:

- тривалість нагріву теплообмінної ділянки $\tau$;

- форма і розміри каналу;

- температура повітря на вході в канал $t_{\mathrm{g}}{ }^{\prime}$;

- температура повітря на виході з каналу в початку періоду нагріву $t_{0 \mathrm{~g}}{ }^{\prime \prime}$;

- температура повітря на виході з каналу в концеперіода нагріву $t_{\tau \mathrm{g}}{ }^{\prime \prime}$;

- початкова температура шару матеріалу $t_{\mathrm{s}}$ i його кінцева температура $t_{\mathrm{s}}$;

- середній потік сонячного випромінювання $Q_{\mathrm{c}}$;

- тривалість процесу нагріву шару матеріалу $\tau_{\Sigma}$;

- кількість каналів регенератора $n$.

Розрахунок проводиться для теплиці, кліматичні умови якої відповідають Одеській області, 3 розмірами 6х3 м, висота стін - 2,5 м. Середня величина теплового потоку сонячного випромінювання в квітні для площі підстави теплиці 18 м²: 
$Q_{0 c}=5840$ Вт. При середній тривалості світлового дня 13,5 годин приймаємо $k=0,37$. При таких умовах $Q_{\mathrm{c}}=2160$ Вт. Розсіяним сонячним випромінюванням нехтуємо.

Схема розташування каналів грунтового регенератора в теплиці приведена на рис. 2.

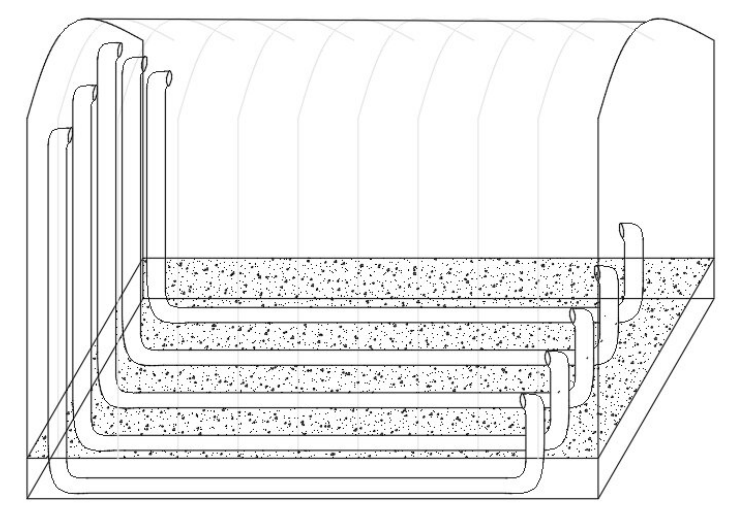

Рисунок 2 - Схема розташування теплообмінних каналів трунтового регенератора в теплиці

Приймаємо, що тривалість нагріву щебню становить 6 годин. Починати нагрів акумулятора рекомендується після того, як температура вгорі теплиці досягне $30^{\circ} \mathrm{C}$.

Як гранульований матеріал обрано щебінь, 3 еквівалентним діаметром частинок $d_{\mathrm{e}}=3,5 \mathrm{~cm}$.

Вихідні дані для розрахунку наступні.

Тривалість нагрівання термічного шару $\tau=1800$ с. Теплообмінний канал - квадратного перетину зі стороною $40 \mathrm{~cm}$. Температура повітря на вході $t_{\mathrm{g}}{ }^{\prime}=30^{\circ} \mathrm{C}$, на виході на початку процесу нагрівання $t_{0 \mathrm{~g}}{ }^{\prime \prime}=18{ }^{\circ} \mathrm{C}$ і в кінці $t_{\tau \mathrm{g}}{ }^{\prime \prime}=29^{\circ} \mathrm{C}$. Початкова температура шару матеріалу $t_{s}^{\prime}=16^{\circ} \mathrm{C}$, кінцева температура $t_{s}{ }^{\prime \prime}=26{ }^{\circ} \mathrm{C}$. Середнє значення потоку сонячного випромінювання $Q_{\mathrm{c}}=2160$ Вт, тривалість процесу нагріву шару матеріалу $\tau_{\Sigma}=6$ годин. Кількість каналів регенератора $n=5$.

Результати розрахунків наведені в табл. 1.

Таблиця 1 - Результати розрахунку грунтового регенератора для теплиці

\begin{tabular}{|l|c|}
\hline Витрата повітря в одному каналі $G_{g}$, кг / с & 0,066 \\
\hline Швидкість фільтрації повітря $w_{f}$, м / с & 0,34 \\
\hline $\begin{array}{l}\text { Середній коефіцієнт міжкомпонентного } \\
\text { теплообміну } \alpha_{\mathrm{av}}, \mathrm{Bт} /\left(\mathrm{m}^{2} \cdot \kappa\right)\end{array}$ & 17 \\
\hline Довжина каналу $L, \mathrm{~m}$ & 5,65 \\
\hline Маса щебню в каналі $m$, кг & 1265 \\
\hline
\end{tabular}

При проведенні розрахунків приймалося, що коефіцієнт форми відповідно до досліджень [6], $\varphi=1,43$. У цьому випадку значення питомої поверхні частинок $a_{s p}=60$.

Оскільки в теплиці розташовується 5 каналів, кількість акумульованої шаром гравію теплоти складе:

$$
Q_{J}=Q_{C} \cdot \tau_{\Sigma}=2161 \cdot 6 \cdot 3600=46,68 \mathrm{MДж}
$$

Акумульовану теплоту передбачається використовувати в нічний час. Слід провести оціночний розрахунок теплових втрат в нічний час. Для даної теплиці площа теплопередавальної поверхні: $F=70,4 \mathrm{~m}^{2}$.

Відповідно до [16], максимальний коефіцієнт тепловіддачі з поверхні теплиці становить $\alpha=8,0$ $\mathrm{BT} /\left(\mathrm{M}^{2} \cdot \mathrm{K}\right)$. Процес охолодження теплиці $\epsilon$ нестаціонарним, причому змінюється температура як навколишнього повітря, так і повітря в теплиці. Однак для оцінки теплових втрат в наближенні середніх температур застосовують закон НьютонаРіхмана [10]:

$$
Q_{\text {Loss }}=\alpha \cdot F \cdot \Delta t \text {. }
$$

Беручи до уваги, що середня температура навколишнього середовища в нічний час $t_{1}=7^{\circ} \mathrm{C}$, а середня температура на поверхні плівки теплиці $t_{2}=16^{\circ} \mathrm{C}, Q_{\text {Loss }}=5069$ Вт. Тоді теплоти, запасеної в акумуляторі, вистачить на $\tau_{n}=9209$ с, або 2,56 години.

Проведений тепловий конструкторський розрахунок дозволяе визначити основні геометричні характеристики регенератора і масу його засипки. Включення і вимикання вентиляторів регенератора має контролюватися датчиками температури повітря в теплиці і на виході з регенератора. Це дозволить ефективно використовувати грунтовий регенератор при різних температурних умовах.

\section{4. Висновки}

Виконано тепловий конструкторський розрахунок регенератора 3 каналами квадратного перетину, заповнених щебнем з еквівалентним розміром частинок 3,5 см. Маса щебню становить 1265 кг. Отримано, що при середньому тепловому потоці в денний час $Q_{\mathrm{c}}=2160$ Вт витрата повітря в одному каналі $G_{g}=0,066$, кг/с, швидкість фільтрації повітря $w_{f}=0,34, \mathrm{~m} / \mathrm{c}$, середній коефіцієнт між- 
компонентного теплообміну $\alpha_{a v}=17 \mathrm{BT} /\left(\mathrm{M}^{2} \cdot \mathrm{K}\right)$, довжина каналу $L=5,75$ м. Для даної теплиці з площею теплопередавальної поверхні $F=70,4$ м² при середній температурі навколишнього середовища в нічний час $t_{1}=7^{\circ} \mathrm{C}$ i середній температурі на поверхні теплиці $t_{2}=16{ }^{\circ} \mathrm{C}$ акумульована теплота може витрачатися протягом не менше 2,5 годин. Протягом цього часу не буде необхідності в використанні обігрівальних приладів. При підвищенні температури навколишнього середовища час роботи регенератора буде збільшуватися, що сприяє більшому зниженню енергетичних витрат на підтримку клімату в теплиці.

\section{Література}

1. Амерханов Р.А., Долинский А.А., Морозюк Т.В. Аккумулирование теплоты в системах теплоснабжения сельского хозяйства // Промышленная теплотехника. - 2002. - Т. 24. - № 1. C. 106-108.

2. Pavel Drabek, Martin Zálešák, Michal Oplustil's. The Impact of the Heat Accumulation on Energy Efficiency of Building // In book: Proceedings of the 26th International DAAAM Symposium 2016. P. 1045-1051.

3. Демченко В., Коник А. Основні аспекти процесів теплоакумулювання // Наукові праці. - 2020. - № 84(1). - C. 48-53

4. Козак Х.Р., Желих В.М. Оцінка та аналіз характеристик теплових акумуляторів для повітряних геліосистем // Вентиляція, освітлення та теплогазопостачання. - 2016. - Вип. 19. - С. 65-69.

5. Ioan Sarbu, Calin Sebarchievici. A Comprehensive Review of Thermal Energy Storage // Sustainability. - 2018. - Vol. 10, Is. 191. - P. 2-32.

6. Solodka A.V., Volgusheva N.V., Boshkova I.L., Titlov A.S., Rozhentsev A.V. Investigation of heat exchange in a blown dense layer of granular materials // East-European Journal of Enterprise Technologies. - 2017. - Vol 5. - No. 8 (89). - P. 58-64.

7. Mesmoudi K., Soudani A., Zitouni B., Bournet P., Serir L. Experimental study of the energy balance of unheated greenhouse under hot and arid climates: Study for the night period of winter season //
Journal of the Association of Arab Universities for Basic and Applied Sciences. - 2010. - Vol. 9, Iss. 1. P. 27-37.

8. Pavlov G., Olesen B. Thermal energy storage - A review of concepts and systems for heating and cooling applications in buildings: Part 1 - Seasonal storage in the ground // Journal HVAC\&R Research. 2012. - Vol. 18, Is. 3. - P. 515-538.

9. Almendros-Ibáñez J.A., Fernández-Torrijos M., Sobrinoc C. A review of solar thermal energy storage in beds of particles: Packed and fluidized beds // Solar Energy. - 2019. - Vol. 192. - No. 1. - P. 193-237.

10. Liu Y., Tao S., Liu X., Wen Z. Three dimensional analysis of gas flow and heat transfer in a regenerator with aluminum balls // Applied Thermal Engineering. - 2014. - Vol. 69 - P. 113-122.

11. Adeyanju A., Manohar K. Theoretical and Experimental Investigation of Heat Transfer in Packed Beds // Research Journal of Applied Sciences. - 2009. - Vol. 4. - No 5. - P. 166-177.

12. Bu S.S., Yang J., Zhou M., Li S.Y., Wang Q.W., Guo Z.X. On contact point modifications for forced convective heat transfer analysis in a structured packed bed of spheres // Nuclear Engineering and Design. - 2014. - Vol. 270. - P. 21-33.

13. Teitel M., Barak M., Antler A. Effect of cyclic heating and a thermal screen on the nocturnal heat loss and microclimate of a greenhouse // Biosystems Engineering. - 2009. - Vol. 102. - P. 162-170.

14. Albrecht K.J., Ho K.C. Heat transfer models of moving packed-bed particle-to-s $\mathrm{CO}_{2}$ heat exchangers // Proceedings of the ASME 2017 Power and Energy Conference Power Energy. - 2017. - Charlotte, North Carolina, USA Power Energy. - P. 331-340.

15. Boshkova I., Volgusheva N., Solodka A., Mukminov I., Bondarenko O. Development of a soil regenerator with a granular nozzle for greenhouses // Eastern-European Journal of Enterprise Technologies. - 2020. - Vol. 4. - No. 8(106). - P. 14-20.

16. Messai S., Ganaoui M. El., Sghaier J., Belghith A. Experimental Study of the Convective Heat Transfer // Thermal science. - 2014. - Vol. 18. No. 2. - P. 443-450.

Отримана в редакції 13.08.2020, прийнята до друку 08.12.2020 


\title{
Efficiency analysis of the greenhouse soil regenerator with a granular nozzle
}

\author{
I. Boshkova ${ }^{1 \bowtie}$, N. Volgusheva ${ }^{2}$, E. Altman $^{3}$, I. Mukminov $^{4}$, A. Hrechanovskyi ${ }^{5}$ \\ ${ }^{1-4}$ Odessa National Academy of Food Technologies, 112 Kanatnaya Str., Odessa, 65039, Ukraine; \\ ${ }^{5}$ Odessa National Polytechnic University, 1 Shevchenko ave., Odessa, 65044, Ukraine \\ $\triangle$ e-mail: ${ }^{1}$ boshkova.irina@gmail.com; ${ }^{2}$ natvolgusheva@gmail.com; ${ }^{3}$ ellaa@ukr.net; ${ }^{4}$ fatalrew@gmail.com \\ ORCID: ${ }^{1}$ http://orcid.org/0000-0001-5989-9223; ${ }^{2}$ http://orcid.org/0000-0002-9984-6502; \\ ${ }^{3}$ http://orcid.org/0000-0001-6454-2819; ${ }^{4}$ https://orcid.org/0000-0002-3674-9289
}

Nowadays it is urgent to find efficient solar energy batteries for space heating in conditions of significant daily temperature differences. As a storage body, it is advisable to use a dense layer of granular materials. The possibility of using a regenerative heat exchanger with a granular packing in the form of a dense layer has been studied. The granulated packing is heated by the air flow from the inside of the greenhouse. The developed regenerator is designed to maintain the required temperature level. The idea of creating a soil regenerator is based on information about the intensity of air heating in the greenhouse from solar radiation in the daytime and the efficiency of contact heat exchange between the air and the layer of particles. The proposed circuit solution assumes air intake from the upper part of the greenhouse, which ensures the supply of air flow into the channel at the maximum temperature. The use of a dense layer of crushed stone as a heat exchange packing is considered. The results of the thermal calculation of the regenerator carried out for a greenhouse with a base area of $18 \mathrm{~m}^{2}$ are presented. Climatic conditions correspond to regions with a temperate climate, for example, the Odessa region. For the average level of insolation, characteristic of April, and a given duration of heating the layer, the main geometric characteristics of the heat exchange channels were determined. The results of calculating heat losses from the greenhouse at night and the time during which the heat accumulated by the regenerator will be used to heat the inner volume of the greenhouse are presented. It was found that the accumulated heat makes it possible to maintain the permissible temperature in the greenhouse for 2,5 hours without using other heating means. As the ambient temperature rises, the operating time of the regenerator will increase, which contributes to a greater reduction in energy costs for maintaining the climate in the greenhouse.

Keywords: Greenhouse; Solar radiation; Heat accumulation; Regenerator; Heat exchange channel; Dense layer.

\section{References}

1. Amerkhanov, R.A., Dolinsky, A.A., Morozyuk, T.V. (2002) Heat accumulation in heat supply systems for agriculture. Industrial heat engineering, 24, 1, 106-108.

2. Drabek, P., Zálešák, M., Oplustil's, M. (2016) The Impact of the Heat Accumulation on Energy Efficiency of Building. In book: Proceedings of the 26th International DAAAM Symposium, 1045-1051.

3. Demchenko, V., Konik, A. (2020) The main aspects of heat storage processes. Scientific works, 84 (1), 48-53.

4. Kozak, Kh.R., Zhelykh, V.M. (2016) Evaluation and analysis of the characteristics of heat accumulators for air solar systems. Ventilation, lighting and heat and gas supply, 19, 65-69.

5. Sarbu, I., Sebarchievici, C. (2018) A Comprehen- sive Review of Thermal Energy Storage. Sustainability, 10, 191, 2-32.

6. Solodka, A.V., Volgusheva, N.V., Boshkova, I.L., Titlov, A.S., Rozhentsev, A.V. (2017) Investigation of heat exchange in a blown dense layer of granular materials. East-European Journal of Enterprise Technologies, 5, 8 (89), 58-64.

7. Mesmoudi, K., Soudani, A., Zitouni, B., Bournet, P., Serir, L. (2010) Experimental study of the energy balance of unheated greenhouse under hot and arid climates: Study for the night period of winter season. Journal of the Association of Arab Universities for Basic and Applied Sciences, 9, 1, 27-37.

8. Pavlov, G., Olesen, B. (2012) Thermal energy storage - A review of concepts and systems for heating and cooling applications in buildings: Part $1-$ Seasonal storage in the ground. Journal HVAC\&R Research, 18, 3, 515-538. 
9. Almendros-Ibáñez, J.A., Fernández-Torrijos, M., Sobrinoc, C. (2019) A review of solar thermal energy storage in beds of particles: Packed and fluidized beds. Solar Energy, 192, 1, 193-237.

10. Liu, Y., Tao, S., Liu, X., Wen, Z. (2014) Three dimensional analysis of gas flow and heat transfer in a regenerator with aluminum balls. Applied Thermal Engineering, 69, 113-122.

11. Adeyanju, A., Manohar, K. (2009) Theoretical and Experimental Investigation of Heat Transfer in Packed Beds. Research Journal of Applied Sciences, 5, 166-177.

12. Bu, S.S., Yang, J., Zhou, M., Li, S.Y., Wang, Q.W., Guo, Z.X. (2014) On contact point modifications for forced convective heat transfer analysis in a structured packed bed of spheres. Nuclear Engineering and Design, 270, 21-33.

13. Teitel, M., Barak, M., Antler, A. (2009) Effect of cyclic heating and a thermal screen on the noctur- nal heat loss and microclimate of a greenhouse. Biosystems Engineering, 102, 162-170.

14. Albrecht, K.J., Ho, K.C. (2017) Heat transfer models of moving packed-bed particle-to-sCO $\mathrm{CO}_{2}$ heat exchangers. Proceedings of the ASME 2017 Power and Energy Conference Power Energy, Charlotte, North Carolina, USA Power Energy, 331-340.

15. Boshkova, I., Volgusheva, N., Solodka, A., Mukminov, I., Bondarenko, O. (2020) Development of a soil regenerator with a granular nozzle for greenhouses. Eastern-European Journal of Enterprise Technologies, 4, 8(106), 14-20.

16. Messai, S., Ganaoui, M. El., Sghaier, J., Belghith, A. (2014) Experimental Study of the Convective Heat Transfer. Thermal science, 18, 2, 443-450.

Received 13 August 2020 Approved 08 December 2020

Available in Internet 11 January 2021 